\title{
MicroRNA expression distinguishes SCLC from NSCLC lung tumor cells and suggests a possible pathological relationship between SCLCs and NSCLCs
}

Liqin Du*1, Jeoffrey J Schageman², Irnov³, Luc Girard4,5, Scott M Hammond8, John D Minna1,4,5,6, Adi F Gazdar1,4,7 and Alexander Pertsemlidis*1,4,6

\begin{abstract}
Background: Recent studies have shown that microRNAs (miRNAs) play roles in tumorigenesis and are reliable classifiers of certain cancer types and subtypes. However, the role of miRNAs in the pathogenesis and diagnosis of small cell carcinoma (SCLC), the majority of which represent the most aggressive lung tumors, has not been investigated.

Methods: In order to explore miRNA involvement in the pathogenesis of small cell lung carcinoma (SCLC) and the potential role of miRNAs in SCLC diagnosis, we compared the miRNA expression profile of a set of SCLC cell lines to that of a set of non-small cell lung cancer (NSCLC) cell lines and normal immortalized human bronchial epithelial cells (HBECS) using microarray analysis.

Results: Our results show that miRNA profiles reliably distinguish SCLC cell lines from NSCLC and HBEC cell lines. Further analysis of the miRNA expression profile of the two subtypes of lung cancer cell lines indicates that the expression levels of the majority of the miRNAs that are differentially expressed in SCLC cells relative to NSCLC cells and HBECs show a progressive trend from HBECS to NSCLC cells to SCLC cells.

Conclusions: The distinctive miRNA expression signature of SCLCs relative to NSCLCs and HBECs suggests that miRNA profiles have the potential to serve as a diagnostic marker of SCLC lung tumors. The progressive trend of miRNA profile changes from HBECs to NSCLCs to SCLCs suggests a possible pathological relationship between SCLCs and NSCLCs, and suggests that the increasing dysregulation of miRNA expression may play a role in lung tumor progression. The specific role of these miRNAs in lung tumor pathogenesis and differentiation need to be investigated further in future studies.
\end{abstract}

\section{Background}

Small cell lung carcinoma (SCLC) is the most aggressive subtype of all lung tumors [1]. The poor survival rate of patients with SCLC is largely due to late detection and the lack of therapeutic regimens specifically targeted to SCLC $[2,3]$; thus, therapeutic improvement depends on a

* Correspondence: Liqin.Du@UTSouthwestern.edu,

Alexander.Pertsemlidis@UTSouthwestern.edu

1 Simmons Comprehensive Cancer Center, UT Southwestern Medical Center, Dallas, Texas, USA

4 Hamon Center for Therapeutic Oncology Research, UT Southwestern Medical Center, Dallas, Texas, USA

Full list of author information is available at the end of the article better understanding of the mechanisms underlying SCLC tumorigenesis and developing targeted therapy for this class of lung cancers. Although decades of work have led to better understanding of the genetic abnormalities in SCLC [1,4], these still cannot completely explain the aggressive phenotype that distinguishes it from other lung cancer subtypes. There is clearly an urgent need for continued efforts to understand SCLC tumorigenesis and to identify early diagnostic markers and therapeutic targets for SCLC.

A recently discovered class of small noncoding RNAs, microRNAs (miRNAs), regulates gene expression pri- 
marily by binding to sequences in the $3^{\prime}$ untranslated region (3'UTR) of expressed mRNAs, resulting in decreased protein expression either by repression of translation or by enhancement of mRNA degradation. miRNAs have been shown to have a variety of regulatory functions and to play roles in controlling cancer initiation and progression [5]. Many studies have demonstrated dysregulation of particular miRNAs in various cancer types and investigated the mechanisms of specific miRNAs in tumorigenesis [5-7]. In the context of lung cancer, several studies have attempted to distinguish the miRNA profiles of histological subtypes showing the potential of miRNA profiles as diagnostic markers for distinguishing specific subtypes, such as squamous cell carcinoma and adenocarcinoma $[8,9]$. Moreover, tumor suppressor genes and oncogenes that play crucial roles in lung tumorigenesis have been demonstrated to be targets of miRNAs [10-12], and manipulation of miRNA levels has been used to control lung cancer cell survival and proliferation in vitro and in vivo [13-16]. Few studies, however, have focused on the role of miRNAs in the pathogenesis of SCLC [17]. Primary tissue specimens are difficult to obtain as most SCLC tumors are not surgically resected $[4,18]$, underscoring the importance of cell lines for studying this disease $[19,20]$. In order to characterize the expression of miRNAs in SCLC and explore the potential role of miRNAs in SCLC tumorigenesis, we profiled and compared the expression levels of a group of miRNAs in a set of lung cancer cell lines, including SCLC and nonsmall cell lung cancer (NSCLC) cell lines and immortalized human bronchial epithelial cells (HBECs).

\section{Materials and methods Cell lines}

19 cell lines (Table 1), including 16 lung cancer cell lines [21], and 3 HBEC cell lines immortalized via ectopic expression of $c d k 4$ and $h T E R T$ [22], were obtained from the Hamon Center for Therapeutic Oncology Research at UT Southwestern Medical Center. All cancer cell lines were grown in RPMI-1640 medium (Sigma, St. Louis, MO) supplemented with $5 \%$ fetal bovine serum. HBECs were grown in KSFM medium supplemented with bovine pituitary extract and recombinant human epidermal growth factor (Gibco, Carlsbad, CA). All cell lines were grown in a humidified atmosphere with $5 \% \mathrm{CO}_{2}$ at $37^{\circ} \mathrm{C}$.

\section{RNA isolation and miRNA microarray}

Total RNA was extracted using TRIzol (Invitrogen, Carlsbad, CA), and labeled with a fluorescent modified dinucleotide (5'-phosphate-cytidyl-uridyl-Cy3-3') using T4 RNA ligase, according to Thomson [23]. Oligonucleotide probes antisense to the published mature sequences for 136 conserved human miRNAs were synthesized and spotted in duplicate on Corning GAPS-2 coated slides using a robotic spotter [23]. Samples were hybridized to the array, along with an equimolar reference oligonucleotide set corresponding to the 136 mature microRNAs, which had been labeled with Cy5. Array images were obtained and analyzed with a GenePix 4000A scanner and GenePix Pro 4.1 software (Axon Instruments). We measured raw signal at $532 \mathrm{~nm}(\mathrm{Cy} 3)$ and $635 \mathrm{~nm}(\mathrm{Cy} 5)$, and the expression level of each miRNA was calculated as the ratio of the intensities for each sample to the reference. We then calculated the relative expression of each miRNA in each cell line by normalizing to the overall signal observed for each cell line measurement, and averaged duplicate spots and replicate cell line measurements.

\section{Hierarchical clustering analysis}

The miRNA expression data was log-transformed, normalized by median centering, and then clustered using the Cluster and TreeView software packages [24]. The entire dataset was clustered both on cell lines and on miRNAs using average linkage hierarchical clustering based on Pearson correlation.

\section{Linear discriminant analysis}

We defined three groups of cell lines based on annotated histology of the tumor from which the cell line was derived \{SCLC, NSCLC and HBEC\}. Each cell line can be considered a point in the multi-dimensional space defined by the miRNA expression. Given the assignment of the cell lines into the three groups, we applied linear discriminant analysis (LDA, using the "lda" function as implemented in the R package MASS) $[25,26]$, which attempts to maximize the ratio of between-group variance to within-group variance of the dataset. The result is a linear combination of features that characterize or separate the groups and can be used to reduce the dimensionality of the data and to visualize the relationships between the groups in expression space.

\section{Statistical analysis}

The significance of differential expression of individual miRNAs between the groups was determined by twotailed unpaired t-test, correcting for multiple comparisons using the Benjamini-Hochberg false discovery rate (FDR) method [27]. The trend in expression of each miRNA across the three groups of cell lines was tested using the Jonckheere-Terpstra test, a non-parametric test for ordered differences among groups [28]. It is designed to detect alternatives of ordered group differences with expression of an individual miRNA increasing or decreasing monotonically across the three ordered groups (SCLCs, NSCLCs and HBECs), which can be expressed as $\mu_{\mathrm{SCLC}} \leq \mu_{\mathrm{NSCLC}} \leq \mu_{\mathrm{HBEC}}\left(\right.$ or $\left.\mu_{\mathrm{SCLC}} \geq \mu_{\mathrm{NSCLC}} \geq \mu_{\mathrm{HBEC}}\right)$, with at least one of the inequalities being strict, where $\mu_{\mathrm{i}}$ denotes the mean expression of a given miRNA in group $i$. 
Table 1: Histological classification of the lung cancer cell lines

\begin{tabular}{|c|c|c|c|c|c|c|}
\hline Cell Line & Tumor Subtype & Age & Ethnicity & Gender & Source & Site \\
\hline $\mathrm{NCl}-\mathrm{H} 146$ & $\mathrm{SCLC}$ & 59 & Caucasian & M & metastasis & bone \\
\hline $\mathrm{NCl}-\mathrm{H} 187$ & SCLC & 47 & Caucasian & M & metastasis & pleural \\
\hline $\mathrm{NCl}-\mathrm{H} 209$ & $\mathrm{SCLC}$ & 55 & Caucasian & M & metastasis & bone \\
\hline $\mathrm{NCl}-\mathrm{H} 526$ & $\mathrm{SCLC}$ & 55 & Caucasian & M & metastasis & bone \\
\hline $\mathrm{NCl}-\mathrm{H} 889$ & $\mathrm{SCLC}$ & 69 & Caucasian & $\mathrm{F}$ & metastasis & lymph \\
\hline $\mathrm{NCl}-\mathrm{H} 1672$ & SCLC & 58 & Caucasian & M & primary & lung \\
\hline $\mathrm{NCl}-\mathrm{H} 2107$ & $\mathrm{SCLC}$ & 36 & Black & M & metastasis & bone \\
\hline $\mathrm{NCl}-\mathrm{H} 2171$ & $\mathrm{SCLC}$ & 50 & Caucasian & M & metastasis & pleural \\
\hline $\mathrm{NCl}-\mathrm{H} 2195$ & SCLC & 67 & Caucasian & M & metastasis & bone \\
\hline $\mathrm{NCl}-\mathrm{H} 157$ & NSCLC (squamous) & 59 & Caucasian & M & metastasis & pleural \\
\hline $\mathrm{NCl}-\mathrm{H} 1819$ & $\begin{array}{l}\text { NSCLC } \\
\text { (adenocarcinoma) }\end{array}$ & 55 & Caucasian & $\mathrm{F}$ & metastasis & lymph \\
\hline $\mathrm{NCl}-\mathrm{H} 2052$ & $\begin{array}{l}\text { NSCLC } \\
\text { (mesothelioma) }\end{array}$ & 65 & Caucasian & M & metastasis & pleural \\
\hline $\mathrm{NCl}-\mathrm{H} 2887$ & NSCLC (squamous) & 31 & unknown & M & primary & lung \\
\hline HCC366 & $\begin{array}{l}\text { NSCLC } \\
\text { (adenosquamous) }\end{array}$ & 80 & unknown & $\mathrm{F}$ & primary & lung \\
\hline HCC1195 & $\begin{array}{l}\text { NSCLC } \\
\text { (adenocarcinoma) }\end{array}$ & 47 & Black & M & primary & lung \\
\hline HCC2450 & NSCLC (squamous) & 52 & Caucasian & M & primary & lung \\
\hline HBEC2-KT & $\begin{array}{l}\text { Immortalized } \\
\text { Normal }\end{array}$ & 68 & & M & NA & lung \\
\hline HBEC3-KT & $\begin{array}{l}\text { Immortalized } \\
\text { Normal }\end{array}$ & 65 & & $\mathrm{~F}$ & NA & lung \\
\hline HBEC4-KT & $\begin{array}{l}\text { Immortalized } \\
\text { Normal }\end{array}$ & 71 & & $\mathrm{~F}$ & NA & lung \\
\hline
\end{tabular}

The lung cancer cell lines were established from tissue specimens obtained from lung cancer patients [73]. The subtype of each lung cancer cell line is based on histological examination of the tumor from which the line was derived. Patient age, ethnicity, and gender are listed along with the source of the tissue sample and the site from which the sample was derived.

\section{Results}

Hierarchical clustering classifies cell lines as distinct groups that are consistent with their histological classification

In order to examine whether miRNA expression is informative in distinguishing SCLC cells from NSCLC cells as well as normal lung cells, we measured the expression levels of 136 miRNAs in a panel of cell lines by miRNA microarray. The panel comprised three groups of cell lines that were derived from human lung tumors or normal human lung tissue, including 9 SCLC cell lines, 7 NSCLC cell lines and 3 HBEC lines (Table 1). After normalization, we clustered the miRNA expression data using unsupervised clustering. As shown in Figure 1, the overall expression profile divides the cell lines into two large groups, recapitulating the histological classification of the cell lines and separating the group of SCLC cell lines from the group of NSCLC and HBEC cell lines. This indicates that the SCLC cell lines have a distinct expres- sion profile from that of NSCLCs and normal HBECs. In addition, the NSCLCs cluster separately from the HBECs, indicating that expression of specific miRNAs can also classify NSCLCs from HBECs, which is consistent with a previous report [29].

\section{Specific miRNAs are expressed at significantly different} levels between the lung cancer cell lines and HBECs as well as between the lung cancer subtypes

While the overall miRNA expression profile clusters the cell lines into groups that are consistent with histological features, the determinants of that clustering are individual miRNAs that are differentially expressed between the groups. Such differentially expressed miRNAs have the potential to serve as diagnostic markers of lung cancer as well as of specific histological subtypes. In order to identify microRNAs with significant differential expression in lung cancer cells relative to HBECs as well as between 


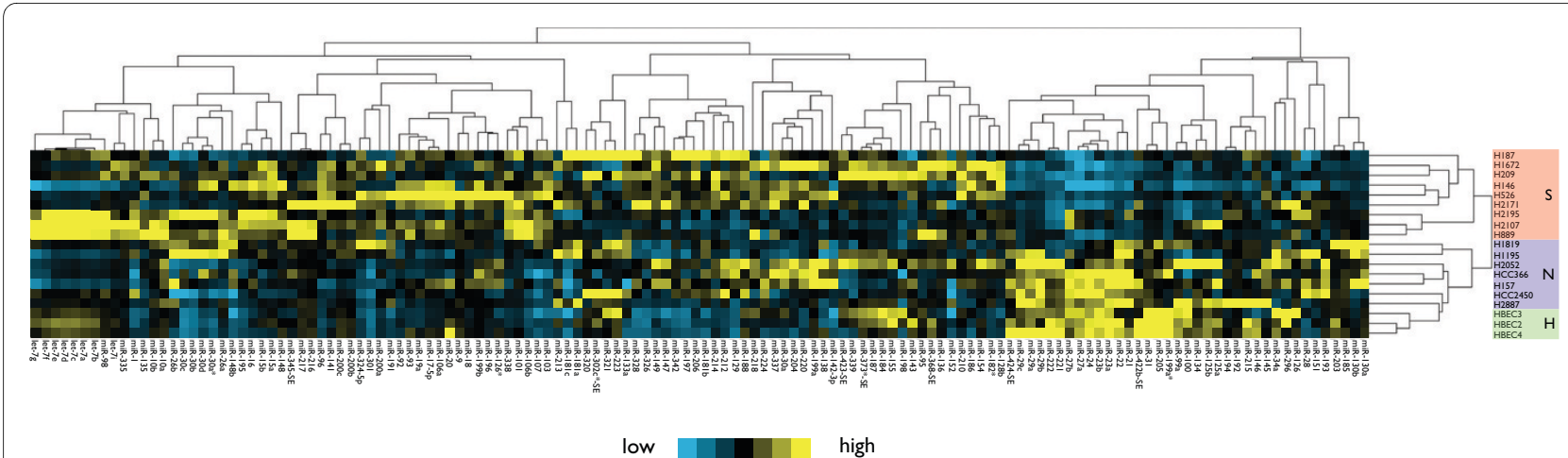

Figure 1 Clustering of cell lines by miRNA expression distinguishes SCLC cell lines from NSCLCs and normal HBECs. Shown is a heatmap representation of the expression of 136 miRNAs in 19 cell lines, with blue indicating relative under-expression and yellow indicating relative over-expression. (S, SCLC; N, NSCLC; H, HBEC).

lung cancer cell subtypes, we divided the set of cell lines into three groups according to the histological classification of the cell lines and the hierarchical clustering results: SCLC (9 samples), NSCLC (7 samples) and HBEC (3 samples), and assessed differential expression of individual miRNAs between the groups by t-test.

Our results identified more miRNAs as classifying SCLC cells from HBECs than as classifying NSCLC cells from HBECs. As shown in Figure 2A, 30 miRNAs were significantly differentially expressed between the SCLC and HBEC cell lines at an FDR-corrected threshold of 0.05 , with 16 miRNAs over-expressed and 14 miRNAs under-expressed in SCLC compared to HBECs. Only two miRNAs (miR-31 and miR-205) were significantly differentially expressed between the NSCLC and HBEC cell lines, as shown in Figure 2B. The comparison between SCLC and NSCLC cell lines is shown in Figure 2C. 29 miRNAs were significantly differentially expressed between the SCLC and NSCLC cell lines, of which 19 are over-expressed in SCLC cell lines relative to NSCLCs and 10 are under-expressed. The miRNAs that are identified as differentially expressed between SCLC cells and NSCLC cells may serve as diagnostic markers for distinguishing SCLC from NSCLC lung tumors.

\section{The miRNA expression profile changes progressively from normal cells to NSCLC to SCLC cells}

Interestingly, the above analysis indicates that more miRNAs are differentially expressed between SCLC cell lines and HBECs than between NSCLC cell lines and HBECs. In addition, the two miRNAs that are significantly differentially expressed in NSCLCs relative to HBECs are included in the group of 30 miRNAs identified as differentially expressed in SCLCs relative to HBECS, as shown in Figure 2A. This suggests a possible pathological relationship between the three groups of cell lines. To examine this relationship, we applied linear discriminant analysis to the three groups of cell lines based on the 41
miRNAs that are identified as significantly differentially expressed as shown in Figure 2. As shown in Figure 3, $88 \%$ of the between-group variance is explained by the first discriminant function with miRNA expression placing NSCLCs between HBECs and SCLC lung tumor cells, suggesting a progressive change in expression from HBECs to NSCLC to SCLC cell lines.

To examine this relationship at the level of individual microRNAs, we applied the Jonckheere-Terpstra test for ordered means to the expression levels of each miRNA in the three groups. This allowed us to assess whether or not the expression trend followed the order \{SCLC, NSCLC, HBEC . As shown in Table 2, of the 26 miRNAs that are over-expressed in SCLC cell lines relative to non-SCLC cell lines, all $26(100 \%)$ show ordered expression at a significance level of 0.05 , with 24 (92\%) showing strict ordering of mean expression levels with SCLC > NSCLC $>$ HBEC. Of the 15 miRNAs that are under-expressed in SCLC cell lines relative to non-SCLCs, 14 (93\%) show ordered expression at a significance level of 0.05 , with 10 (66\%) showing strict ordering of mean expression levels with SCLC $<$ NSCLC $<$ HBEC. These results suggest that expression of a set of miRNA changes progressively from normal cells to NSCLC tumor cells to SCLC tumor cells.

\section{Discussion}

miRNAs have been intensively investigated as diagnostic markers in various cancers and cancer subtypes $[5,6,30]$. However, few studies have specifically investigated the diagnostic value of miRNA profiles in SCLCs. In this study, we show that more miRNAs are differentially expressed between SCLC cell lines and HBECs than between NSCLC cell lines and HBECs; only two miRNAs were significantly differentially expressed between the NSCLCs and HBEC cell lines. The similarity between the HBEC and NSCLC miRNA profiles reflects the close histological relationship between HBECs and NSCLCs [31- 


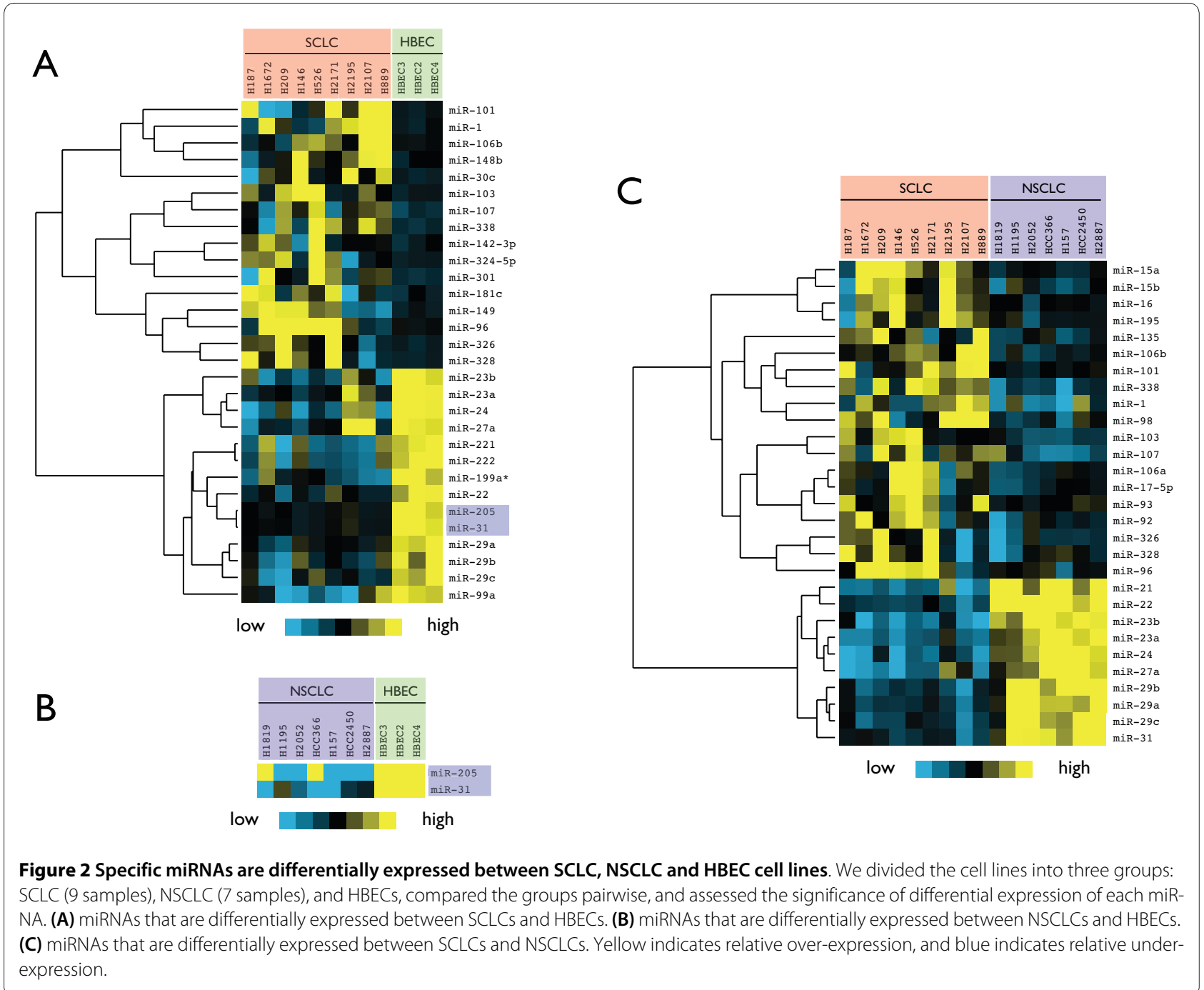

33]. On the other hand, the distinctive miRNA expression signature of SCLCs as compared with NSCLCs and HBECs suggests the possibility of developing miRNA profiling as a diagnostic tool for distinguishing SCLCs from NSCLCs and normal lung tissues. The development of miRNA profiling as a diagnostic tool could potentially benefit SCLC diagnosis from two perspectives. First, miRNA profiling would add a more quantitative aspect to the diagnosis of SCLC. Although the SCLCs share common genetic abnormalities and histological features and represent the most aggressive subtype of lung cancer in general, the survival and prognosis of SCLC patients diagnosed at the same stage vary $[34,35]$, suggesting that quantitative molecular traits are related to the degree of malignancy. However, current diagnosis of SCLC is primarily determined histologically [36], which is not sufficient to quantitatively evaluate malignancy and prognosis. Several studies have shown that miRNA expression levels are related to cancer prognosis [37-40].
Similarly, the quantification of aberrant expression levels of miRNAs in SCLCs may serve as a reliable tool for the prediction of SCLC prognosis. Second, the miRNAs identified as over-expressed in SCLCs may serve as early and non-invasive detection markers. Recent findings have shown that miRNAs are secreted into blood and are detectable in serum, showing potential as non-invasive markers for diseases $[41,42]$. Inexpensive, non-invasive detection methods are suitable for the development of large-scale screening of high-risk populations and may therefore significantly advance the early diagnosis of cancers. Given the aggressive nature of most SCLCs, the development of highly sensitive and specific non-invasive molecular diagnostics based on miRNA profiling could be of great clinical benefit. Overall, the miRNAs identified as differentially expressed in SCLC compared to NSCLC and normal cells hold promise as early, noninvasive and quantitative markers of SCLCs and warrant further investigation. 


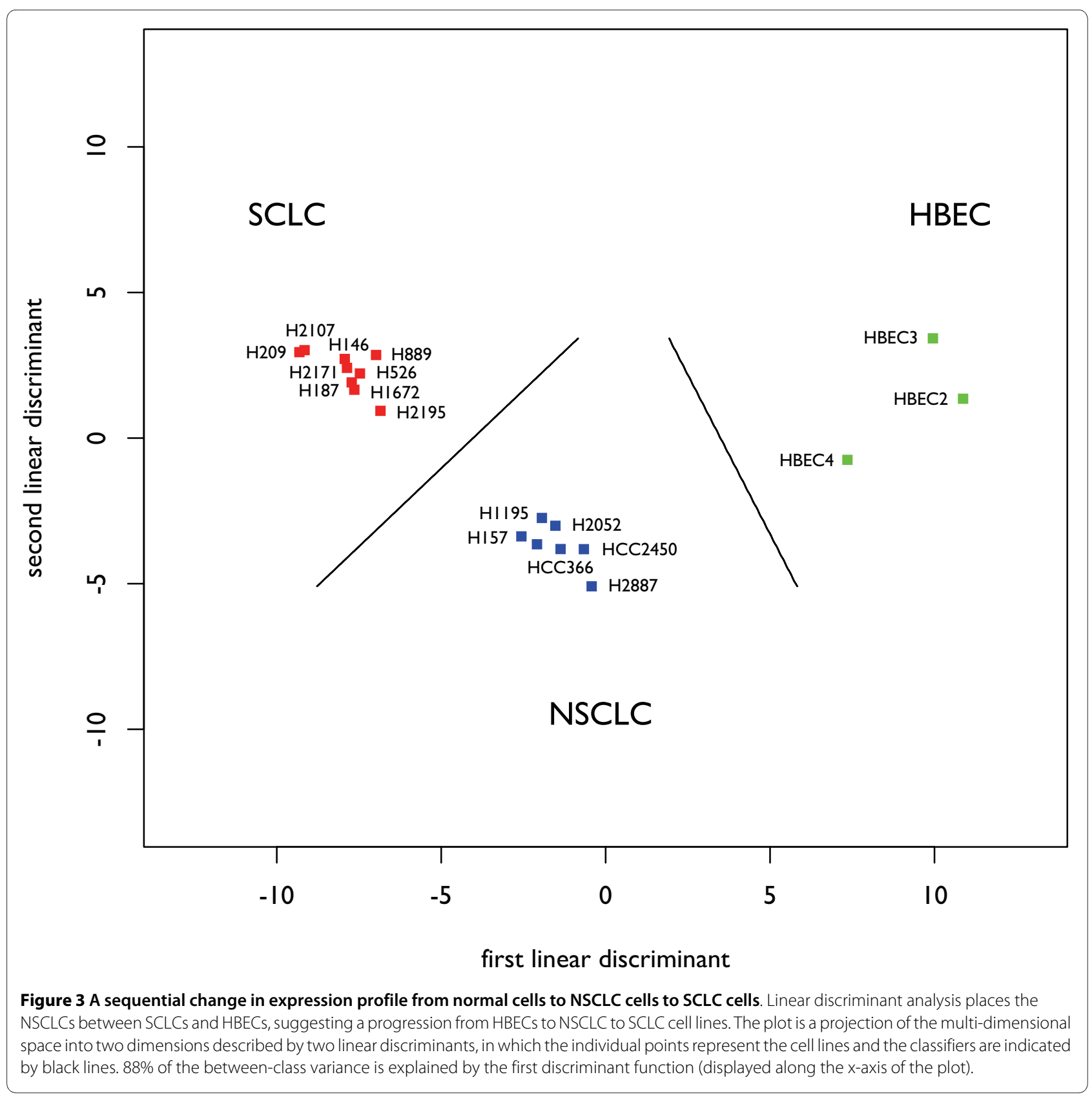

Our results suggest that miRNAs may play an important role in the pathogenesis of SCLCs. Although there is evidence to support NSCLCs as originating from HBECs [31-33], the findings on the histological origin of SCLC remain somewhat controversial [43-45]. Previous studies suggest that a transition between NSCLC and SCLC can occur during lung tumor progression and that neuroendocrine differentiation of NSCLCs, which has been postulated to be an intermediate step between NSCLC and SCLC, is related to poor prognosis and early metastasis [46-48]. However, the mechanisms involved in this transition between the two subtypes are not completely understood. Our results show that of the 41 miRNAs that are differentially expressed between the three groups of cell lines, 34 (83\%) show a trend of progressive differential expression from HBECs to NSCLCs to SCLCs (Table 2). These results support the hypothesis that differential expression of miRNAs could contribute to the differentiation of lung cancer cells from one subtype to another, in which SCLC could result from NSCLC cells by gradually acquiring SCLC properties through the cumulative dysregulation of miRNAs, and that manipulating the levels of specific miRNAs levels might prevent the differentiation of lung cancer cells toward a more malignant phenotype.

Changes in miRNA expression can lead to tumorigenesis, but the many complex interactions between miRNAs 
Table 2: Sequential changes in expression of individual miRNAs that are differentially expressed between the cell line groups

\begin{tabular}{|c|c|c|c|c|c|c|c|c|c|c|c|}
\hline miRNA & SCLC & NSCLC & HBEC & $\begin{array}{c}\text { SCLC } \\
\text { NSCLC }\end{array}$ & $\begin{array}{l}\text { SCLC } \\
\text { HBEC }\end{array}$ & $\begin{array}{c}\text { NSCLC } \\
\text { HBEC }\end{array}$ & $\begin{array}{l}\text { p SCLC } \\
\text { NSCLC }\end{array}$ & p SCLC HBEC & $\begin{array}{c}\text { p NSCLC } \\
\text { HBEC }\end{array}$ & pJT & Location \\
\hline \multicolumn{12}{|c|}{ Over-expressed in SCLC cell lines } \\
\hline $\operatorname{miR}-338$ & $0.47 \pm 0.16$ & $0.08 \pm 0.04$ & $0.01 \pm 0.00$ & 5.71 & 47.33 & 8.29 & $1.62 \mathrm{E}-03$ & $8.08 \mathrm{E}-03$ & $2.38 \mathrm{E}-01$ & $1.99 \mathrm{E}-05$ & $17 q 25.3$ \\
\hline miR-101 & $2.46 \pm 1.10$ & $0.52 \pm 0.25$ & $0.25 \pm 0.08$ & 4.72 & 9.72 & 2.06 & $5.22 \mathrm{E}-03$ & $3.50 \mathrm{E}-02$ & $4.20 \mathrm{E}-01$ & $6.41 \mathrm{E}-05$ & $1 \mathrm{p} 31.3,9 \mathrm{p} 24.1$ \\
\hline miR-98 & $1.79 \pm 0.86$ & $0.51 \pm 0.27$ & $0.62 \pm 0.11$ & 3.52 & 2.91 & 0.83 & $1.56 \mathrm{E}-02$ & $1.12 \mathrm{E}-01$ & $7.49 \mathrm{E}-01$ & $8.96 \mathrm{E}-03$ & Xp11.22 \\
\hline miR-106b & $0.47 \pm 0.20$ & $0.15 \pm 0.08$ & $0.07 \pm 0.01$ & 3.26 & 6.78 & 2.08 & $1.03 \mathrm{E}-02$ & $3.41 \mathrm{E}-02$ & $4.20 \mathrm{E}-01$ & $3.31 \mathrm{E}-05$ & $7 q 22.1$ \\
\hline miR-17-5p & $1.07 \pm 0.57$ & $0.33 \pm 0.19$ & $0.29 \pm 0.07$ & 3.25 & 3.72 & 1.15 & $2.95 \mathrm{E}-02$ & $1.12 \mathrm{E}-01$ & $8.56 \mathrm{E}-01$ & $9.49 \mathrm{E}-04$ & $13 q 31.3$ \\
\hline miR-106a & $1.26 \pm 0.59$ & $0.41 \pm 0.23$ & $0.31 \pm 0.05$ & 3.10 & 4.06 & 1.31 & $1.96 \mathrm{E}-02$ & $7.11 \mathrm{E}-02$ & $7.39 \mathrm{E}-01$ & $6.25 \mathrm{E}-04$ & Xq26.2 \\
\hline miR-96 & $0.73 \pm 0.28$ & $0.26 \pm 0.10$ & $0.12 \pm 0.05$ & 2.77 & 6.24 & 2.25 & $1.03 \mathrm{E}-02$ & $3.14 \mathrm{E}-02$ & $3.36 \mathrm{E}-01$ & $4.62 \mathrm{E}-05$ & $7 q 32.2$ \\
\hline miR-15a & $0.45 \pm 0.15$ & $0.17 \pm 0.04$ & $0.18 \pm 0.08$ & 2.63 & 2.55 & 0.97 & $5.12 \mathrm{E}-03$ & $5.48 \mathrm{E}-02$ & $9.39 \mathrm{E}-01$ & $3.49 \mathrm{E}-03$ & $13 q 14.3$ \\
\hline miR-92 & $0.44 \pm 0.17$ & $0.17 \pm 0.08$ & $0.15 \pm 0.04$ & 2.54 & 2.96 & 1.16 & $1.33 \mathrm{E}-02$ & $5.48 \mathrm{E}-02$ & $7.91 \mathrm{E}-01$ & $5.42 \mathrm{E}-04$ & $\mathrm{Xq} 26.2$ \\
\hline miR-326 & $0.49 \pm 0.20$ & $0.20 \pm 0.11$ & $0.05 \pm 0.01$ & 2.49 & 10.45 & 4.19 & $2.45 \mathrm{E}-02$ & $2.71 \mathrm{E}-02$ & $3.36 \mathrm{E}-01$ & $1.04 \mathrm{E}-04$ & $11 q 13.4$ \\
\hline miR-1 & $0.09 \pm 0.03$ & $0.04 \pm 0.03$ & $0.01 \pm 0.01$ & 2.40 & 6.42 & 2.68 & $3.92 \mathrm{E}-02$ & $2.71 \mathrm{E}-02$ & $5.04 \mathrm{E}-01$ & $1.24 \mathrm{E}-03$ & $20 q 13.33,18 q 11.2$ \\
\hline miR-15b & $0.63 \pm 0.24$ & $0.26 \pm 0.09$ & $0.23 \pm 0.10$ & 2.39 & 2.78 & 1.17 & $1.56 \mathrm{E}-02$ & 7.07E-02 & $7.75 \mathrm{E}-01$ & $2.72 \mathrm{E}-03$ & $3 q 26.1$ \\
\hline miR-195 & $2.74 \pm 1.23$ & $1.19 \pm 0.45$ & $0.60 \pm 0.06$ & 2.30 & 4.55 & 1.98 & $3.51 \mathrm{E}-02$ & $5.48 \mathrm{E}-02$ & $3.36 \mathrm{E}-01$ & $4.06 \mathrm{E}-04$ & $17 p 13.1$ \\
\hline miR-103 & $0.91 \pm 0.26$ & $0.41 \pm 0.11$ & $0.29 \pm 0.07$ & 2.23 & 3.16 & 1.42 & $5.12 \mathrm{E}-03$ & $1.99 \mathrm{E}-02$ & $4.20 \mathrm{E}-01$ & 7.54E-05 & $5 q 35.1,20 p 13$ \\
\hline miR-135 & $0.28 \pm 0.12$ & $0.13 \pm 0.03$ & $0.08 \pm 0.02$ & 2.19 & 3.41 & 1.56 & $2.95 \mathrm{E}-02$ & $6.50 \mathrm{E}-02$ & $3.36 \mathrm{E}-01$ & $2.25 \mathrm{E}-04$ & $3 p 21.1,12 q 23.1$ \\
\hline miR-301 & $0.74 \pm 0.28$ & $0.35 \pm 0.44$ & $0.05 \pm 0.02$ & 2.12 & 15.95 & 7.53 & $1.14 \mathrm{E}-01$ & $1.68 \mathrm{E}-02$ & $5.04 \mathrm{E}-01$ & $2.72 \mathrm{E}-03$ & $17 q 22,22 q 11.21$ \\
\hline miR-328 & $0.76 \pm 0.31$ & $0.36 \pm 0.19$ & $0.04 \pm 0.03$ & 2.12 & 19.06 & 9.00 & $4.42 \mathrm{E}-02$ & $2.24 \mathrm{E}-02$ & $2.38 \mathrm{E}-01$ & $1.42 \mathrm{E}-04$ & $16 q 22.1$ \\
\hline miR-93 & $0.94 \pm 0.38$ & $0.45 \pm 0.09$ & $0.42 \pm 0.13$ & 2.07 & 2.23 & 1.07 & $2.95 \mathrm{E}-02$ & $1.12 \mathrm{E}-01$ & $7.94 \mathrm{E}-01$ & $8.27 \mathrm{E}-04$ & $7 q 22.1$ \\
\hline miR-16 & $1.04 \pm 0.40$ & $0.51 \pm 0.15$ & $0.33 \pm 0.10$ & 2.03 & 3.14 & 1.55 & $2.95 \mathrm{E}-02$ & $5.48 \mathrm{E}-02$ & $4.20 \mathrm{E}-01$ & $5.42 \mathrm{E}-04$ & $13 q 14.3,3 q 26.1$ \\
\hline miR-324-5p & $0.43 \pm 0.16$ & $0.22 \pm 0.22$ & $0.09 \pm 0.03$ & 1.95 & 4.80 & 2.46 & $1.14 \mathrm{E}-01$ & $3.18 \mathrm{E}-02$ & $5.93 \mathrm{E}-01$ & $1.24 \mathrm{E}-03$ & $17 p 13.1$ \\
\hline miR-107 & $0.71 \pm 0.13$ & $0.38 \pm 0.13$ & $0.27 \pm 0.09$ & 1.86 & 2.62 & 1.41 & $4.74 \mathrm{E}-03$ & $4.78 \mathrm{E}-03$ & $4.64 \mathrm{E}-01$ & $1.66 \mathrm{E}-04$ & $10 q 23.31$ \\
\hline miR-149 & $0.24 \pm 0.08$ & $0.15 \pm 0.12$ & $0.07 \pm 0.03$ & 1.56 & 3.58 & 2.29 & $2.12 \mathrm{E}-01$ & $3.18 \mathrm{E}-02$ & 4.99E-01 & $5.02 \mathrm{E}-03$ & $2 q 37.3$ \\
\hline miR-181c & $0.39 \pm 0.12$ & $0.25 \pm 0.12$ & $0.13 \pm 0.07$ & 1.52 & 2.91 & 1.91 & $1.14 \mathrm{E}-01$ & $3.20 \mathrm{E}-02$ & 4.26E-01 & 4.45E-03 & $19 p 13.12$ \\
\hline miR-148b & $0.24 \pm 0.10$ & $0.17 \pm 0.11$ & $0.06 \pm 0.04$ & 1.39 & 4.24 & 3.05 & $3.38 \mathrm{E}-01$ & $4.69 \mathrm{E}-02$ & $4.20 \mathrm{E}-01$ & $5.00 \mathrm{E}-02$ & $12 q 13.13$ \\
\hline miR-142-3p & $0.13 \pm 0.05$ & $0.10 \pm 0.07$ & $0.03 \pm 0.02$ & 1.31 & 4.03 & 3.09 & 4.11E-01 & $4.46 \mathrm{E}-02$ & $4.20 \mathrm{E}-01$ & $1.72 \mathrm{E}-02$ & $17 q 22$ \\
\hline miR-30c & $2.97 \pm 0.87$ & $2.47 \pm 1.34$ & $1.12 \pm 0.09$ & 1.20 & 2.65 & 2.20 & $4.72 \mathrm{E}-01$ & $3.18 \mathrm{E}-02$ & $4.20 \mathrm{E}-01$ & $5.00 \mathrm{E}-02$ & $1 p 34.2,6 q 13$ \\
\hline
\end{tabular}


Table 2: Sequential changes in expression of individual miRNAs that are differentially expressed between the cell line groups (Continued)

\begin{tabular}{|c|c|c|c|c|c|c|c|c|c|c|c|}
\hline \\
\hline miR-199a* & \multicolumn{11}{|c|}{ Under-expressed in SCLC cell lines } \\
\hline miR-27a & $0.31 \pm 0.23$ & $0.74 \pm 0.27$ & $0.90 \pm 0.10$ & 0.42 & 0.35 & 0.83 & $2.73 \mathrm{E}-02$ & $1.86 \mathrm{E}-02$ & $6.07 \mathrm{E}-01$ & $1.42 \mathrm{E}-03$ & $19 p 13.12$ \\
\hline miR-23b & $1.86 \pm 0.79$ & $5.29 \pm 1.55$ & $5.89 \pm 0.65$ & 0.35 & 0.32 & 0.90 & $1.99 \mathrm{E}-03$ & $4.21 \mathrm{E}-04$ & 7.49E-01 & $1.93 \mathrm{E}-04$ & $9 q 22.32$ \\
\hline miR-222 & $0.47 \pm 0.46$ & $1.33 \pm 1.07$ & $2.40 \pm 0.67$ & 0.35 & 0.19 & 0.55 & $1.14 \mathrm{E}-01$ & $3.23 \mathrm{E}-03$ & $4.26 \mathrm{E}-01$ & $1.09 \mathrm{E}-03$ & Xp11.3 \\
\hline miR-221 & $0.77 \pm 0.83$ & $2.19 \pm 1.44$ & $3.51 \pm 1.17$ & 0.35 & 0.22 & 0.62 & $9.69 \mathrm{E}-02$ & $1.10 \mathrm{E}-02$ & $4.64 \mathrm{E}-01$ & $6.25 \mathrm{E}-04$ & Xp11.3 \\
\hline miR-99a & $0.28 \pm 0.19$ & $0.85 \pm 0.70$ & $0.93 \pm 0.20$ & 0.33 & 0.30 & 0.91 & $1.03 \mathrm{E}-01$ & $5.64 \mathrm{E}-03$ & $9.25 \mathrm{E}-01$ & $8.00 \mathrm{E}-03$ & $21 q 21.1$ \\
\hline miR-24 & $0.62 \pm 0.39$ & $1.93 \pm 0.70$ & $2.05 \pm 0.12$ & 0.32 & 0.30 & 0.94 & $5.12 \mathrm{E}-03$ & $2.80 \mathrm{E}-03$ & $8.76 \mathrm{E}-01$ & $8.27 \mathrm{E}-04$ & $9 q 22.32,19 p 13.12$ \\
\hline miR-29c & $0.56 \pm 0.20$ & $1.97 \pm 1.13$ & $1.59 \pm 0.71$ & 0.29 & 0.36 & 1.24 & $1.75 \mathrm{E}-02$ & $1.68 \mathrm{E}-02$ & 7.86E-01 & $1.25 \mathrm{E}-02$ & $1 \mathrm{q} 32.2$ \\
\hline miR-23a & $1.19 \pm 0.74$ & $4.32 \pm 1.83$ & $5.76 \pm 0.96$ & 0.27 & 0.21 & 0.75 & $5.12 \mathrm{E}-03$ & $2.50 \mathrm{E}-04$ & 4.97E-01 & 4.70E-04 & $19 p 13.12$ \\
\hline miR-205 & $0.45 \pm 0.15$ & $1.86 \pm 3.04$ & $18.38 \pm 4.63$ & 0.24 & 0.02 & 0.10 & $3.03 \mathrm{E}-01$ & 9.67E-06 & $9.08 \mathrm{E}-03$ & $1.79 \mathrm{E}-01$ & $1 \mathrm{q} 32.2$ \\
\hline miR-29b & $0.72 \pm 0.33$ & $3.07 \pm 1.49$ & $2.31 \pm 1.38$ & 0.23 & 0.31 & 1.33 & $5.22 \mathrm{E}-03$ & $3.18 \mathrm{E}-02$ & $7.14 \mathrm{E}-01$ & $8.00 \mathrm{E}-03$ & $7 q 32.3,1 q 32.2$ \\
\hline miR-29a & $0.75 \pm 0.29$ & $4.08 \pm 2.53$ & $3.73 \pm 1.63$ & 0.18 & 0.20 & 1.09 & $1.27 \mathrm{E}-02$ & $3.23 \mathrm{E}-03$ & $9.07 \mathrm{E}-01$ & $6.36 \mathrm{E}-03$ & $7 q 32.3$ \\
\hline miR-22 & $0.05 \pm 0.02$ & $0.33 \pm 0.07$ & $0.24 \pm 0.12$ & 0.16 & 0.22 & 1.39 & $3.55 \mathrm{E}-06$ & $5.64 \mathrm{E}-03$ & $4.26 \mathrm{E}-01$ & $1.85 \mathrm{E}-03$ & 17p13.3 \\
\hline miR-21 & $4.35 \pm 6.37$ & $27.93 \pm 10.26$ & $11.01 \pm 4.60$ & 0.16 & 0.39 & 2.54 & $1.99 \mathrm{E}-03$ & $2.23 \mathrm{E}-01$ & $2.73 E-01$ & $1.91 \mathrm{E}-02$ & $17 q 23.1$ \\
\hline miR-31 & $0.04 \pm 0.06$ & $0.64 \pm 0.39$ & $5.65 \pm 0.96$ & 0.07 & 0.01 & 0.11 & $5.22 \mathrm{E}-03$ & 3.85E-07 & $2.34 \mathrm{E}-04$ & $2.25 \mathrm{E}-04$ & $9 p 21.3$ \\
\hline
\end{tabular}


and their targets that occur during these processes are not fully understood. A variety of studies have linked miRNA dysregulation with malignant transformation [49]. However, the role of miRNAs in SCLC pathogenesis has not been extensively studied. Our investigation identified a group of miRNAs that show a progressive differential expression from HBECs to NSCLC and SCLC cells. Several of the miRNAs identified in this study have been shown to be associated with various cancer types in previous studies. For example, we found significant overexpression of miR-103, miR-107, miR-301 and miR-338 in lung cancer cells as compared to HBECs. These miRNAs have been shown to be over-expressed in several types of cancers including lung cancers [17,50,51], and high expression of miR-103 and miR-107 were correlated with poor survival in cancer patients (esophageal squamous and pancreatic tumors) [51,52]. These miRNAs might contribute to common pathways during the transformation of normal cells to tumor cells during lung cancer pathogenesis, and the greater extent of aberrant expression of these miRNAs in SCLCs relative to NSCLCs might contribute to the more aggressive phenotype of the former.

Our study also identified a group of miRNAs that might contribute to the establishment of SCLC features and the specific phenotypes that differentiate SCLC from NSCLC. For example, we found over-expression of miR17-5p in SCLCs compared to NSCLCs. This miRNA was recently shown to target $\mathrm{Rbl} 2$, a member of the $\mathrm{Rb}$ family [53]. $\mathrm{Rb}$ is a tumor suppressor that induces arrest of the cell cycle at G1 [54]. SCLCs have been shown to exhibit loss of $\mathrm{Rb}$ expression in $87-100 \%$ of tumors compared to less than 15\% in NSCLC [55-57]. SCLC cells were also previously shown to be addicted to continued overexpression of miR-17-5p [58], and forced over-expression of the miRNA cluster that includes miR-17-5p (miR-1792) was shown to induce embryonic lung epithelial cell proliferation [59]. Coupled with these data, our results suggest that dysregulation of this miRNA could be an important distinction that defines the pathogenesis and phenotypic characteristics of SCLC compared to NSCLC. We also observed a significant increase in miR-135 expression in SCLC cells compared to NSCLC cells. miR135 has recently been shown to inhibit expression of the tumor suppressor gene Adenomatous Polyposis Coli (APC) in colorectal cancer [60]. Loss of heterozygosity of APC has been shown in both small cell and non-small cell lung cancers, but appears to be more frequent in SCLC [61]. Silencing of this gene by CpG hypermethylation, however, is more frequent in NSCLC compared to SCLC [62], suggesting that various lung tumor subtypes could use different means to down-regulate this tumor suppressor. These findings suggest that SCLC preferentially utilizes microRNA-based regulatory mechanisms to reduce
APC expression. miR-29a, $-29 b$ and $-29 c$ expression was shown be significantly down-regulated in SCLC cells compared to HBECs, whereas these reductions were not seen in NSCLC cells. Expression levels of miR-29a, miR$29 \mathrm{~b}$, and miR-29c were previously shown to be inversely correlated with levels of DNA methyltransferase (DNMT) -3A and -3B [14], two key enzymes involved in DNA methylation that have been shown to promote tumorigenesis [63]. Forced expression of these miRNAs also inhibited tumorigenicity in vitro and in vivo [14]. In SCLC cells, but not NSCLC cells, we also observed significant reductions in miR-24, inhibition of which was previously shown to enhance cell proliferation [64]. These miRNAs might contribute to the specific pathogenesis pathways during the transformation of SCLCs but not NSCLCs.

Several miRNAs identified in our study exhibited expression levels not consistent with previous observations in other cancer types, suggesting contextual dependence of miRNA function in the regulation of tumorigenesis pathways. For example, we observed significantly increased levels of miR-148b in SCLC compared to HBECs; miR-148b has been shown to target DNMT3B [65], with down-regulation of miR-148b observed in metastatic cancers [66]. miR-21, miR-221 and miR-222, which have been shown to be oncogenic miRNAs and up-regulated in certain lung cancer subtypes $[67,68]$, are significantly down-regulated in SCLC. We speculate that these miRNAs may not be the primary driving force for controlling SCLC cell proliferation and survival. Given the large number of miRNAs that are found aberrantly expressed in SCLCs, it is possible that some of these miRNAs play crucial roles in pathogenesis of SCLC. The oncogenic pathways up-regulated by these miRNAs might lead to feedback up-regulation of certain tumor suppressor miRNAs and down-regulation of certain oncogenic miRNAs. Further studies are certainly needed to address this question. We also observed upregulation of miR-142-3p in SCLC compared to HBECs, although a previous report showed significant repression of this miRNA in lung adenocarcinomas versus normal tissue [69]. Another study showed down-regulation of this miRNA early in tumor development followed by increased expression at the later stages of lung tumorigenesis [70]. Expression levels of this miRNA could therefore vary both with lung tumor subtype and stage of tumor development. miR-1 has also been shown to be expressed at lower levels in lung cancer cell lines, including both NSCLC and SCLC, than in bronchial epithelial cells [71], whereas our results show significant overexpression of miR-1 in lung cancer cell lines compared to HBECs. However, given the extremely low expression levels observed in both the normal bronchial epithelial cells and lung cancer cells in our study, and in normal lung tis- 
sues in other studies [71,72], the aberrant expression of miR-1 in lung cancers relative to normal lung cells needs to be evaluated further.

\section{Conclusions}

In summary, our study raises several interesting questions regarding the role of miRNAs in pathogenesis and diagnosis of SCLC. We addressed the potential of miRNA profiling as a diagnostic tool for distinguishing SCLC from NSCLC and normal lung epithelial cells. In addition, our study revealed for the first time that the group of miRNAs that are differentially expressed between lung cancer cell lines and normal lung epithelial cells shows a trend from HBECs to NSCLC cells to SCLC cells, suggesting that increased dysregulation of miRNA expression might be involved in the progression of lung tumors toward a more malignant subtype. Further study on a larger scale is certainly needed to fully define the potential of miRNAs as diagnostic markers of SCLC, as well as the role of specific miRNAs in the pathogenesis of SCLC.

\section{Abbreviations}

SCLC: small cell lung carcinoma; NSCLC: non-small cell lung carcinoma; HBEC: human bronchial epithelial cell.

\section{Competing interests}

The authors declare that they have no competing interests.

\section{Authors' contributions}

JDM and AFG derived the cell lines, LG isolated the RNA, SMH ran the arrays, and JJS and I performed data analysis. LD and AP designed the study, analyzed the data and wrote the manuscript. All authors read and approved the final manuscript.

\section{Acknowledgements \\ The authors gratefully acknowledge the technical assistance of Paul Card, J. Michael Thomson and Summer Goodson and thank Michael Peyton for thoughtful insights and discussions, and for critical reading of the manuscript. This work was supported in part by Public Health Service grant number P50 CA70907 from the UT Southwestern/MD Anderson Cancer Center Lung Spe- cialized Program of Research Excellence (UTSW/MDACC Lung SPORE) and the National Cancer Institute and grant number R01 CA129632 from the National Institutes of Health and the National Cancer Institute.}

\section{Author Details}

1Simmons Comprehensive Cancer Center, UT Southwestern Medical Center, Dallas, Texas, USA, 2McDermott Center for Human Growth and Development, UT Southwestern Medical Center, Dallas, Texas, USA, ${ }^{3}$ Division of Basic Sciences, Southwestern Graduate School of Biomedical Sciences, UT Southwestern Medical Center, Dallas, Texas, USA, ${ }^{4 H a m o n}$ Center for Therapeutic Oncology Research, UT Southwestern Medical Center, Dallas, Texas, USA, ${ }^{5}$ Department of Pharmacology, UT Southwestern Medical Center, Dallas, Texas, USA, ${ }^{6}$ Department of Internal Medicine, UT Southwestern Medical Center, Dallas, Texas, USA, ${ }^{7}$ Department of Pathology, UT Southwestern Medical Center, Dallas, Texas, USA and ${ }^{8}$ Lineberger Comprehensive Cancer Center, School of Medicine, University of North Carolina School at Chapel Hill, Chapel Hill, North Carolina, USA

Received: 7 May 2010 Accepted: 17 June 2010

Published: 17 June 2010

\section{References}

1. Jackman DM, Johnson BE: Small-cell lung cancer. Lancet 2005, 366:1385-1396.
2. Schiller JH: Current standards of care in small-cell and non-small-cell lung cancer. Oncology 2001, 61(Suppl 1):3-13.

3. Asamura H, Kameya T, Matsuno Y, Noguchi M, Tada H, Ishikawa Y, Yokose T, Jiang SX, Inoue T, Nakagawa K, Tajima K, Nagai K: Neuroendocrine neoplasms of the lung: a prognostic spectrum. J Clin Oncol 2006, 24:70-76.

4. Sher T, Dy GK, Adjei AA: Small cell lung cancer. Mayo Clin Proc 2008 , 83:355-367

5. Garzon R, Calin GA, Croce CM: MicroRNAs in Cancer. Annu Rev Med 2009, 60:167-179.

6. Lynam-Lennon N, Maher SG, Reynolds JV: The roles of microRNA in cancer and apoptosis. Biol Rev Camb Philos Soc 2009, 84:55-71.

7. Mirnezami AH, Pickard K, Zhang L, Primrose JN, Packham G: MicroRNAs: key players in carcinogenesis and novel therapeutic targets. Eur I Surg Oncol 2009, 35:339-347.

8. Bishop JA, Benjamin H, Cholakh H, Chajut A, Clark DP, Westra WH: Accurate classification of non-small cell lung carcinoma using a novel microRNA-based approach. Clin Cancer Res 2010, 16:610-619.

9. Lebanony D, Benjamin H, Gilad S, Ezagouri M, Dov A, Ashkenazi K, Gefen N, Izraeli S, Rechavi G, Pass H, Nonaka D, Li J, Spector Y, Rosenfeld N, Chajut A, Cohen D, Aharonov R, Mansukhani M: Diagnostic assay based on hsa-miR-205 expression distinguishes squamous from nonsquamous non-small-cell lung carcinoma. J Clin Oncol 2009, 27:2030-2037.

10. Ortholan C, Puissegur MP, llie M, Barbry P, Mari B, Hofman P: MicroRNAs and lung cancer: new oncogenes and tumor suppressors, new prognostic factors and potential therapeutic targets. Curr Med Chem 2009, 16:1047-1061.

11. Wu X, Piper-Hunter MG, Crawford M, Nuovo GJ, Marsh CB, Otterson GA, Nana-Sinkam SP: MicroRNAs in the pathogenesis of lung cancer. $J$ Thorac Oncol 2009, 4:1028-1034

12. Du L, Schageman JJ, Subauste MC, Saber B, Hammond SM, Prudkin L, Wistuba II, Ji L, Roth JA, Minna JD, Pertsemlidis A: miR-93, miR-98, and miR-197 regulate expression of tumor suppressor gene FUS1. Mol Cancer Res 2009, 7:1234-1243.

13. Johnson CD, Esquela-Kerscher A, Stefani G, Byrom M, Kelnar K Ovcharenko D, Wilson M, Wang X, Shelton J, Shingara J, Chin L, Brown D, Slack FJ: The let-7 microRNA represses cell proliferation pathways in human cells. Cancer Res 2007, 67:7713-7722.

14. Fabbri M, Garzon R, Cimmino A, Liu Z, Zanesi N, Callegari E, Liu S, Alder H, Costinean S, Fernandez-Cymering C, Volinia S, Guler G, Morrison CD, Chan KK, Marcucci G, Calin GA, Huebner K, Croce CM: MicroRNA-29 family reverts aberrant methylation in lung cancer by targeting DNA methyltransferases 3A and 3B. Proc Natl Acad Sci USA 2007, 104:15805-15810

15. Kumar MS, Erkeland SJ, Pester RE, Chen CY, Ebert MS, Sharp PA, Jacks T: Suppression of non-small cell lung tumor development by the let-7 microRNA family. Proc Natl Acad Sci USA 2008, 105:3903-3908.

16. Cho WC, Chow AS, Au JS: Restoration of tumour suppressor hsa-miR145 inhibits cancer cell growth in lung adenocarcinoma patients with epidermal growth factor receptor mutation. Eur J Cancer 2009. 45:2197-2206.

17. Miko E, Czimmerer Z, Csanky E, Boros G, Buslig J, Dezso B, Scholtz B: Differentially expressed microRNAs in small cell lung cancer. Exp Lung Res 2009, 35:646-664.

18. Brock MV, Hooker CM, Syphard JE, Westra W, Xu L, Alberg AJ, Mason D, Baylin SB, Herman JG, Yung RC, Brahmer J, Rudin CM, Ettinger DS, Yang SC: Surgical resection of limited disease small cell lung cancer in the new era of platinum chemotherapy: Its time has come. J Thorac Cardiovasc Surg 2005, 129:64-72.

19. Gazdar AF, Gao B, Minna JD: Lung cancer cell lines: Useless artifacts or invaluable tools for medical science? Lung Cancer 2010, 68:309-318.

20. Pleasance ED, Stephens PJ, O'Meara S, McBride DJ, Meynert A, Jones D, Lin ML, Beare D, Lau KW, Greenman C, Varela I, Nik-Zainal S, Davies HR, Ordonez GR, Mudie LJ, Latimer C, Edkins S, Stebbings L, Chen L, Jia M, Leroy C, Marshall J, Menzies A, Butler A, Teague JW, Mangion J, Sun YA, McLaughlin SF, Peckham HE, Tsung EF, et al:: A small-cell lung cancer genome with complex signatures of tobacco exposure. Nature 2010, 463:184-190.

21. Gazdar AF, Carney DN, Nau MM, Minna JD: Characterization of variant subclasses of cell lines derived from small cell lung cancer having 
distinctive biochemical, morphological, and growth properties. Cancer Res 1985, 45:2924-2930.

22. Ramirez RD, Sheridan S, Girard L, Sato M, Kim Y, Pollack J, Peyton M, Zou Y, Kurie JM, Dimaio JM, Milchgrub S, Smith AL, Souza RF, Gilbey L, Zhang X, Gandia K, Vaughan MB, Wright WE, Gazdar AF, Shay JW, Minna JD: Immortalization of human bronchial epithelial cells in the absence of viral oncoproteins. Cancer Res 2004, 64:9027-9034.

23. Thomson JM, Parker J, Perou CM, Hammond SM: A custom microarray platform for analysis of microRNA gene expression. Nat Methods 2004, 1:47-53.

24. Eisen MB, Spellman PT, Brown PO, Botstein D: Cluster analysis and display of genome-wide expression patterns. Proc Natl Acad Sci USA 1998, 95:14863-14868

25. Venables WN, Ripley BD: Modern Applied Statistics with S. 4th edition. New York: Springer; 2003.

26. R Development Core Team: R: A Language and Environment for Statistical Computing. Vienna, Austria: R Foundation for Statistical Computing; 2009.

27. Benjamini Y, Hochberg Y: Controlling the false discovery rate: a practical and powerful approach to multiple testing. Journal of the Royal Statistical Society 1995, 57:289-300.

28. Conover WJ: Practical Nonparametric Statistics. New York: John Wiley \& Sons; 1998

29. Landi MT, Zhao Y, Rotunno M, Koshiol J, Liu H, Bergen AW, Rubagotti M, Goldstein AM, Linnoila I, Marincola FM, Tucker MA, Bertazzi PA, Pesatori AC, Caporaso NE, MCShane LM, Wang E: MicroRNA expression differentiates histology and predicts survival of lung cancer. Clin Cancer Res 2010, 16:430-441

30. Calin GA, Croce CM: MicroRNA signatures in human cancers. Nat Rev Cancer 2006, 6:857-866.

31. Nowell PC: The clonal evolution of tumor cell populations. Science 1976, 194:23-28.

32. Sato M, Vaughan MB, Girard L, Peyton M, Lee W, Shames DS, Ramirez RD, Sunaga N, Gazdar AF, Shay JW, Minna JD: Multiple oncogenic changes (K-RAS(V12), p53 knockdown, mutant EGFRs, p16 bypass, telomerase) are not sufficient to confer a full malignant phenotype on human bronchial epithelial cells. Cancer Res 2006, 66:2116-2128.

33. Wistuba II, Gazdar AF: Lung cancer preneoplasia. Annu Rev Pathol 2006, 1:331-348.

34. Puglisi M, Dolly S, Faria A, Myerson JS, Popat S, O'Brien ME: Treatment options for small cell lung cancer - do we have more choice? Br J Cancer 2010, 102:629-638.

35. de Ruysscher D: Treatment of limited disease small cell lung cancer. Front Radiat Ther Oncol 2010, 42:173-179.

36. Beasley MB, Brambilla E, Travis WD: The 2004 World Health Organization classification of lung tumors. Semin Roentgenol 2005, 40:90-97.

37. Yanaihara N, Caplen N, Bowman E, Seike M, Kumamoto K, Yi M, Stephens RM, Okamoto A, Yokota J, Tanaka T, Calin GA, Liu CG, Croce CM, Harris CC: Unique microRNA molecular profiles in lung cancer diagnosis and prognosis. Cancer Cell 2006, 9:189-198.

38. Garzon R, Volinia S, Liu CG, Fernandez-Cymering C, Palumbo T, Pichiorri F, Fabbri M, Coombes K, Alder H, Nakamura T, Flomenberg N, Marcucci G, Calin GA, Kornblau SM, Kantarjian H, Bloomfield CD, Andreeff M, Croce CM: MicroRNA signatures associated with cytogenetics and prognosis in acute myeloid leukemia. Blood 2008, 111:3183-3189.

39. Schetter AJ, Leung SY, Sohn JJ, Zanetti KA, Bowman ED, Yanaihara N, Yuen ST, Chan TL, Kwong DL, Au GK, Liu CG, Calin GA, Croce CM, Harris CC: MicroRNA expression profiles associated with prognosis and therapeutic outcome in colon adenocarcinoma. JAMA 2008, 299:425-436.

40. Calin GA, Ferracin M, Cimmino A, Di Leva G, Shimizu M, Wojcik SE, lorio MV, Visone R, Sever NI, Fabbri M, Iuliano R, Palumbo T, Pichiorri F, Roldo C, Garzon R, Sevignani C, Rassenti L, Alder H, Volinia S, Liu CG, Kipps TJ, Negrini M, Croce CM: A MicroRNA signature associated with prognosis and progression in chronic lymphocytic leukemia. N Engl J Med 2005, 353:1793-1801.

41. Mitchell PS, Parkin RK, Kroh EM, Fritz BR, Wyman SK, Pogosova-Agadjanyan EL, Peterson A, Noteboom J, O'Briant KC, Allen A, Lin DW, Urban N, Drescher CW, Knudsen BS, Stirewalt DL, Gentleman R, Vessella RL, Nelson PS, Martin DB, Tewari M: Circulating microRNAs as stable blood-based markers for cancer detection. Proc Natl Acad Sci USA 2008, 105:10513-10518.
42. Chen X, Ba Y, Ma L, Cai X, Yin Y, Wang K, Guo J, Zhang Y, Chen J, Guo X, Li Q, Li X, Wang W, Wang J, Jiang X, Xiang Y, Xu C, Zheng P, Zhang J, Li R, Zhang H, Shang X, Gong T, Ning G, Zen K, Zhang CY: Characterization of microRNAs in serum: a novel class of biomarkers for diagnosis of cancer and other diseases. Cell Res 2008, 18:997-1006.

43. Watkins DN, Berman DM, Burkholder SG, Wang B, Beachy PA, Baylin SB: Hedgehog signalling within airway epithelial progenitors and in smallcell lung cancer. Nature 2003, 422:313-317.

44. Giangreco A, Groot KR, Janes SM: Lung cancer and lung stem cells: strange bedfellows? Am J Respir Crit Care Med 2007, 175:547-553.

45. Kitamura H, Yazawa T, Sato H, Okudela K, Shimoyamada H: Small cell lung cancer: significance of RB alterations and TTF-1 expression in its carcinogenesis, phenotype, and biology. Endocr Pathol 2009, 20:101-107.

46. Graziano SL, Tatum AH, Newman NB, Oler A, Kohman LJ, Veit LJ, Gamble GP, Coleman MJ, Barmada S, O'Lear S: The prognostic significance of neuroendocrine markers and carcinoembryonic antigen in patients with resected stage I and II non-small cell lung cancer. Cancer Res 1994, 54:2908-2913.

47. Linnoila RI, Piantadosi S, Ruckdeschel JC: Impact of neuroendocrine differentiation in non-small cell lung cancer. The LCSG experience. Chest 1994, 106:367S-371S.

48. Risse-Hackl G, Adamkiewicz J, Wimmel A, Schuermann M: Transition from SCLC to NSCLC phenotype is accompanied by an increased TREbinding activity and recruitment of specific AP-1 proteins. Oncogene 1998, 16:3057-3068.

49. Croce CM: Causes and consequences of microRNA dysregulation in cancer. Nat Rev Genet 2009, 10:704-714.

50. Yu T, Wang XY, Gong RG, Li A, Yang S, Cao YT, Wen YM, Wang CM, Yi XZ: The expression profile of microRNAs in a model of 7,12-dimethylbenz[a]anthrance-induced oral carcinogenesis in Syrian hamster. J Exp Clin Cancer Res 2009, 28:64.

51. Roldo C, Missiaglia E, Hagan JP, Falconi M, Capelli P, Bersani S, Calin GA, Volinia S, Liu CG, Scarpa A, Croce CM: MicroRNA expression abnormalities in pancreatic endocrine and acinar tumors are associated with distinctive pathologic features and clinical behavior. $J$ Clin Oncol 2006, 24:4677-4684.

52. Guo Y, Chen Z, Zhang L, Zhou F, Shi S, Feng X, Li B, Meng X, Ma X, Luo M, Shao K, Li N, Qiu B, Mitchelson K, Cheng J, He J: Distinctive microRNA profiles relating to patient survival in esophageal squamous cell carcinoma. Cancer Res 2008, 68:26-33.

53. Lu Y, Thomson JM, Wong HY, Hammond SM, Hogan BL: Transgenic overexpression of the microRNA miR-17-92 cluster promotes proliferation and inhibits differentiation of lung epithelial progenitor cells. Dev Biol 2007, 310:442-453.

54. Sherr CJ: Cancer cell cycles. Science 1996, 274:1672-1677.

55. Beasley MB, Lantuejoul S, Abbondanzo S, Chu WS, Hasleton PS, Travis WD, Brambilla E: The P16/cyclin D1/Rb pathway in neuroendocrine tumors of the lung. Hum Pathol 2003, 34:136-142.

56. Dosaka-Akita H, Cagle PT, Hiroumi H, Fujita M, Yamashita M, Sharma A, Kawakami Y, Benedict WF: Differential retinoblastoma and p16(INK4A) protein expression in neuroendocrine tumors of the lung. Cancer 2000, 88:550-556.

57. Brambilla E, Moro D, Gazzeri S, Brambilla C: Alterations of expression of $\mathrm{Rb}, \mathrm{p} 16(\mathrm{INK} 4 \mathrm{~A})$ and cyclin D1 in non-small cell lung carcinoma and their clinical significance. J Pathol 1999, 188:351-360.

58. Hayashita Y, Osada H, Tatematsu Y, Yamada H, Yanagisawa K, Tomida S, Yatabe Y, Kawahara K, Sekido Y, Takahashi T: A polycistronic microRNA cluster, miR-17-92, is overexpressed in human lung cancers and enhances cell proliferation. Cancer Res 2005, 65:9628-9632.

59. Ventura A, Young AG, Winslow MM, Lintault L, Meissner A, Erkeland SJ, Newman J, Bronson RT, Crowley D, Stone JR, Jaenisch R, Sharp PA, Jacks T: Targeted deletion reveals essential and overlapping functions of the miR-17 through 92 family of miRNA clusters. Cell 2008, 132:875-886.

60. Nagel R, le Sage C, Diosdado B, van der Waal M, Oude Vrielink JA, Bolijn A, Meijer GA, Agami R: Regulation of the adenomatous polyposis coli gene by the miR-135 family in colorectal cancer. Cancer Res 2008, 68:5795-5802.

61. D'Amico D, Carbone DP, Johnson BE, Meltzer SJ, Minna JD: Polymorphic sites within the MCC and APC loci reveal very frequent loss of heterozygosity in human small cell lung cancer. Cancer Res 1992, 52:1996-1999. 
62. Pan S, Zhang L, Gao L, Gu B, Wang F, Xu J, Shu Y, Yang D, Chen Z: The property of methylated APC gene promotor and its influence on lung cancer cell line. Biomed Pharmacother 2009, 63:463-468.

63. Lin RK, Hsu HS, Chang JW, Chen CY, Chen JT, Wang YC: Alteration of DNA methyltransferases contributes to $5^{\prime} \mathrm{CpG}$ methylation and poor prognosis in lung cancer. Lung Cancer 2007, 55:205-213.

64. Lal A, Navarro F, Maher CA, Maliszewski LE, Yan N, O'Day E, Chowdhury D, Dykxhoorn DM, Tsai P, Hofmann O, Becker KG, Gorospe M, Hide W, Lieberman J: miR-24 inhibits cell proliferation by targeting E2F2, MYC, and other cell-cycle genes via binding to "seedless" 3'UTR microRNA recognition elements. Mol Cell 2009, 35:610-625.

65. Duursma AM, Kedde M, Schrier M, le Sage C, Agami R: miR-148 targets human DNMT3b protein coding region. RNA 2008, 14:872-877.

66. Le X, Merchant O, Bast RC, Calin GA: The Roles of MicroRNAs in the Cancer Invasion-Metastasis Cascade. Cancer Microenvironment 2010 in press.

67. Garofalo M, Quintavalle C, Di Leva G, Zanca C, Romano G, Taccioli C, Liu $\mathrm{CG}$, Croce CM, Condorelli G: MicroRNA signatures of TRAIL resistance in human non-small cell lung cancer. Oncogene 2008, 27:3845-3855.

68. Seike M, Goto A, Okano T, Bowman ED, Schetter AJ, Horikawa I, Mathe EA, Jen J, Yang P, Sugimura H, Gemma A, Kudoh S, Croce CM, Harris CC: MiR21 is an EGFR-regulated anti-apoptotic factor in lung cancer in neversmokers. Proc Natl Acad Sci USA 2009, 106:12085-12090.

69. Liu X, Sempere LF, Galimberti F, Freemantle SJ, Black C, Dragnev KH, Ma Y, Fiering S, Memoli V, Li H, DiRenzo J, Korc M, Cole CN, Bak M, Kauppinen S, Dmitrovsky E: Uncovering growth-suppressive microRNAs in lung cancer. Clin Cancer Res 2009, 15:1177-1183.

70. Mascaux C, Laes JF, Anthoine G, Haller A, Ninane V, Burny A, Sculier JP: Evolution of microRNA expression during human bronchial squamous carcinogenesis. Eur Respir J 2009, 33:352-359.

71. Nasser MW, Datta J, Nuovo G, Kutay H, Motiwala T, Majumder S, Wang B, Suster S, Jacob ST, Ghoshal K: Down-regulation of micro-RNA-1 (miR-1) in lung cancer. Suppression of tumorigenic property of lung cancer cells and their sensitization to doxorubicin-induced apoptosis by miR1. J Biol Chem 2008, 283:33394-33405.

72. Zhao Y, Samal E, Srivastava D: Serum response factor regulates a muscle-specific microRNA that targets Hand2 during cardiogenesis. Nature 2005, 436:214-220

73. Phelps RM, Johnson BE, Ihde DC, Gazdar AF, Carbone DP, McClintock PR, Linnoila Rl, Matthews MJ, Bunn PA Jr, Carney D, Minna JD, Mulshine JL: NCI-Navy Medical Oncology Branch cell line data base. J Cell Biochem Supp/ 1996, 24:32-91.

doi: $10.1186 / 1756-9966-29-75$

Cite this article as: Du et al., MicroRNA expression distinguishes $S C L C$ from NSCLC lung tumor cells and suggests a possible pathological relationship between SCLCs and NSCLCs Journal of Experimental \& Clinical Cancer Research 2010, 29:75

Submit your next manuscript to BioMed Central and take full advantage of:

- Convenient online submission

- Thorough peer review

- No space constraints or color figure charges

- Immediate publication on acceptance

- Inclusion in PubMed, CAS, Scopus and Google Scholar

- Research which is freely available for redistribution

Submit your manuscript at www.biomedcentral.com/submit
C Biomed Central 